\title{
A sensitivity analysis of the European Union coastal zone based on environmental and socio-economic sustainability indicators
}

\author{
A. Kull, T. Oja \& Ü. Mander \\ Institute of Geography, University of Tartu, Estonia
}

\begin{abstract}
Coastal zones, which have a very high biodiversity value and a long history of being impacted by human activities, are among the most vulnerable ecosystems on our planet. Moreover, some scenarios predict that within 50 years more than $75 \%$ of the global human population will live in coastal zones. Although Europe's coasts are among the most altered, there are significant regional differences within Europe in terms of naturalness and human pressure. During the integrated SENSOR project of the European Union's (EU) $6^{\text {th }}$ Framework Programme, we have analyzed the sensitivity of the EU's coastal zones using data on 191 coastal cells at The Nomenclature of Territorial Units for Statistics (NUTS) level, based on information from the Statistical Office of the European Community (EUROSTAT) and other Europe-level sources. To determine sensitive coastal areas, multidimensional clustering was provided. The NUTSx level (a combination of NUTS2 and NUTS3 level cells in order to achieve better spatial coverage) clustering resulted in seven clusters which were not, however, well distinguished in terms of the SENSOR sensitivity areas concept. Therefore clustering on the NUTS2 level was provided using 15 parameters characterizing economic, social and environmental aspects, yielding six clusters that were logically distinguishable from each other. The cluster characterized by a rapidly growing economy combined with relatively high but decreasing unemployment, low but increasing income, a low rate of investment in research and development (R\&D), a low share of arable land but a high rural population, moderate length of coastline with the highest share of coast exposed to coastal erosion and a highly variable level of environmental protection, including 23 coastal NUTS2 areas plus five islands, has to be considered sensitive and needs further attention from the European Commission.

Keywords: coastal zone, designated areas, European Union, GDP, sensitivity analysis, SENSOR, sustainability assessment.
\end{abstract}




\section{Introduction}

Coastal zones, which have a very high biodiversity value and a long history of being impacted by human activities, are among the most vulnerable ecosystems on our planet [1]. The expansion of economic activities, urbanization, increased resource use and population growth continuously increase the vulnerability of the coastal zone. This vulnerability is now raised further by the threat of climate change and accelerated sea level rise [2]. Moreover, according to some scenarios, in 50 years more than $75 \%$ of the global human population will live in coastal zones [3], while six billion people are already expected to live in the coastal zone by 2025 . Although Europe's coasts are among the most altered ones in the world, there are significant regional differences within Europe in terms of naturalness and human pressure [4]. The sensitivity (vulnerability) of coastal areas has been recognized by many authors and authorities. The reason for this is the high pressure from a developing economy (tourism and recreation, rising GDP, traditional coastal fisheries etc.), increasing human population and the environmental sensitivity of the coast. The last issue is related to problems such as the dramatic loss of biodiversity [5], climate-change-driven sea level rise $[6,2]$, storm and tsunami hazards, increasing erosion and seawater intrusion into freshwater sources [7].

The problems of assessing coastal areas in the development of planning and policies are highly relevant. As presented by several authors [8, 9], integrated coastal zone management (ICZM) is recognised as the most effective tool to incorporate the conservation and sustainable use of marine and coastal biodiversity aspects into the planning of coastal areas. Therefore the growing concerns about the deterioration of the European coastline, environmentally, socio-economically and culturally, have prompted the European Commission (EC) and Member States to introduce a range of measures since 1996. It is intended that these measures will lead to the sustainable development of the whole European coast in the future. The first of these was the Commission's Demonstration Programme. This 3 year programme [10] included 35 individual projects and six thematic studies, embracing the Baltic Sea, the North Sea, the Atlantic seaboard and the Mediterranean Sea, and was launched in 1996. It was a joint programme of the three Directorates General, viz. Environment, Regional Development and Fisheries. Its aim was to test co-operation models for the integrated management of the coastal zones and to stimulate a broad debate among the various stakeholders involved in coastal planning and the management or use of the coastal zones. It was also intended to provide the technical results necessary to foster dialogue between the European Institutions and coastal stakeholders. Based on the results of this programme, the European Commission has subsequently produced two important documents on the subject of the ICZM. The first of these is a strategy for the EC [11] concerning the implementation of the ICZM throughout the EU coastal states. This 38-point strategy consists of a series of concrete actions building upon existing instruments, programmes and resources and is a flexible, evolving instrument designed to cope with the specific needs of the different regions and conditions. 
One of the activities (no. 27) calls for the improvement of data provision and the use of this data to produce indicator-based assessment reports. The second document is a recommendation [12], which was called for as the first point of the strategy. This recommendation, although not legally binding, has now been adopted for implementation by all member states. The EU $6^{\text {th }}$ Framework integrated SENSOR project can also be added to this list [13].

The sustainability of coastal areas has been addressed by many authors. Researchers have analysed general questions of the sustainability of coastal zones and options to evaluate sustainability in different regions of the world $[14,15]$ or compared to the effectiveness of policies in different regions [16]. In some cases specific indicators have been offered for the measurement of sustainability, and applied to certain regions [9, 17, 18]. A number of studies deal with different aspects of coastal zone management $[\ulcorner 19,20]$, including economic aspects [21] and legislative measures [22]. In particular, in many cases integrated means for management are seen as a useful tool [23-25].

Planning as a tool for management is also found to be useful [26], the importance of public participation in the planning process is underlined [27], and the development of a vision for the future [28] is accentuated. The management of knowledge [29], the resolution of conflicts between different interest groups [30], capacity building in the local community [31] and a clear understanding of the role of stakeholders [32], is found to be critical to achieve sustainability in social aspects.

Numerous papers address methodological questions or specific methods for coastal zone management and research [33], including tools like environmental impact assessment [34], remote sensing and GIS and mapping in coastal zone management [35]. In addition, the methodological aspects of upscaling downscaling have been addressed in the comparison of local solutions and European perspectives [36].

The impact of tourism and urbanisation has been found to be a very highpressure factor in coastal areas [37]. More specific aspects of sustainability have also been addressed, for instance water quality [38] and resource management in coastal waters - aquaculture [39], fishing or mussel cultivation [40]. The results of the quantitative assessment of habitat and nutrient fluxes in coastal areas as an environmental factor were analysed [41, 42]. The increased amount of research on coastal areas is demonstrated by many papers reporting different research projects directed towards coastal areas [43, 44]. Also, options for the measurement of sustainability and different indicators useful for management schemes and policies are addressed. For example, Spangenberger and Hinterberger (as presented by Spangerberger [18]) have offered a two-layer indicator system for the European Union, based on the concept of environmental space and four different types of capital. The first layer includes unidimensional key indicators and the second adds indicators linking the key indicators. In another study, Shi et al. [17] have calculated the sustainability of coastal areas in Shanghai, China, using a similar set of indicators.

The objectives of the study are to compile an overview of the location of sensitive regions in European coastal areas and define a methodology for the 
identification of key environmental, social and economic sustainability issues. This overview should help test the SENSOR project's Sustainability Impact Assessment Tool (SIAT) [13] and be linked to a methodology and map for European Integrated Spatial Reference Framework and sustainability issues identified in the extensive and intensive social studies.

We consider sensitivity to be a ratio of conflicts between different aspects of development and conservation issues [45]. An example of possible conflicts is given in Table 1.

Table 1: $\quad$ Matrix of possible conflicts between selected sustainability factors. The numbers in the table show the tension level between the factors. NH - natural hazards, NC - nature conservation, D development, $\mathrm{R}$ - restoration, TEU - traditional economic use.

\begin{tabular}{lccccc}
\hline & NH & NC & D & R & TEU \\
\hline NH & $\mathrm{x}$ & & & & \\
NC & 1 & $\mathrm{x}$ & & & \\
D & 3 & 3 & $\mathrm{x}$ & & \\
R & 2 & 1 & 2 & $\mathrm{x}$ & \\
TEU & 2 & 1 & 3 & 2 & $\mathrm{x}$ \\
\hline
\end{tabular}

\section{Material and methods}

\subsection{Coastal NUTSx areas}

The analysis was performed on the basis of NUTSx regions that have a shoreline. NUTSx regions located no more than $10 \mathrm{~km}$ from the shoreline and having access to the sea via a river (Antwerpen, Oost-Vlaanderen, Comunidad Foral de Navarra) were also included. The exploration and evaluation of existing data, information and expert knowledge, results of ongoing and targeted research, and the generation of complementary information on social, economic, and environmental issues were gathered in an iterative way.

\subsection{Data sources}

Statistical data/indicator values were obtained from EUROSTATS for the NUTS2 level and from national statistics for the NUTS3 level. In addition, available Map Data such as CORINE Land Cover (CLC) 1990 and CLC 2000 were used. CLC changes indicate possible endangered areas (not all areas of change are necessarily sensitive). Available CORINE Biotopes layers were also analysed. Two European R\&D projects - LACOAST and EUROSION - have addressed the environmental sensitivity of coastal zones in the $10 \mathrm{~km}$ strip along almost the whole coast of the EU. Data from these two projects was used in the study.

LACOAST (a General Directorate Environment of the European Commission in 2002-2004). The analysis was performed on the basis of CLC1990 and 
comparative Landsat imagery from 1970, in the case of AC 3 (with the exception of Turkey), Belgium, Denmark, Estonia, Finland, France, Germany, Greece, Ireland, Italy, Latvia, Lithuania, the Netherlands, Poland, Portugal, Slovenia, Spain and the United Kingdom.

EUROSION (a General Directorate Environment of the European Commission project in 2002-2004). The project geocoded CORINE Biotopes for AC 3 (with the exception of Turkey), Austria, Belgium, Denmark, Estonia, Finland, France, Germany, Greece, Ireland, Italy, Latvia, Lithuania, the Netherlands, Poland, Portugal, Spain and the United Kingdom), and actually covers a broader area than just the coast. The data available on the EEA site (http://www.eea.eu.int/main_html) forms the background for the analysis of changes that have taken place after 1990. UNDP Human Development Indicators were used (http://hdr.undp.org/statistics/data/).

\subsection{Statistical analysis of the data}

The coastal areas were analysed through combined indicators. The data available for NUTSx areas was preferred [47], and in cases where direct data for NUTS3 areas was not available, data from the relevant NUTS2 area was used instead. The indicator values were calculated for all NUTSx cells. Maps were produced using ArcGIS 9.1 and the ETRS89 Lambert Azimuthal Equal Area projection.

Multidimensional clustering (k-means statistics) with selected indicators was provided in order to highlight possible NUTSx areas sensitive to several factors using Statistica 7.

\section{Results and discussion}

\subsection{Environmental and socio-economic factors characterizing sustainability}

Environmental values and the loss of highly valued areas characterize sustainability issues. The number of designated areas can be considered to be an indicator of ecological value and awareness (Fig. 1). Also, the total length of the coastline and the proportion of the coast affected by erosion appeared to be important for clustering.

Population density and the changes therein is another important factor that characterizes the pressure and affects sustainability. In multifactorial clustering, population density appeared to be an important factor. A change in land use in the area is one of the leading sustainability factors, with the share of agricultural land and forested land having the greatest effect (Fig. 2). Other aspects of land use (the share of arable land and grasslands and changes in land use as demonstrated by a comparison of land use in 1990 and 2003, also show the sustainability of the cell. Purchasing power and the amount of money circulating in the area are also definitely important factors characterizing the pressures on the environment and thus the sustainability of the area. The increase of GDP in coastal areas is presented in Fig. 3 and 4. The rapid growth of GDP may be considered more dangerous, as the formation of stability requires time, and a 
rapid increase in financial means may initiate a development that could endanger sustainability. The rapid growth of GDP is characteristics of the Baltic countries, Ireland, Poland and parts of the UK. Portugal and Greece also have a relatively high increase in GDP.

\subsection{Multidimensional clustering}

Clustering has been widely used to classify environmental, social and economic phenomena and combinations thereof [47].

In order to determine clusters of similar NUTSx areas, two attempts at cluster analysis were provided using selected indicators characterizing different aspects of sustainability. The unevenness of the data at the NUTSx level caused very high variability, and the clusters distinguished are not informative for the further selection of sensitive clusters. Therefore clustering was performed at the NUTS2 level using the same k-means clustering option.

\subsubsection{Clustering at the NUTS2 level}

At NUTS2 level we changed the selection of sustainability factors on the basis of our experience from the first clustering attempt. The results of this exercise are presented in Table 2 and Figure 5.

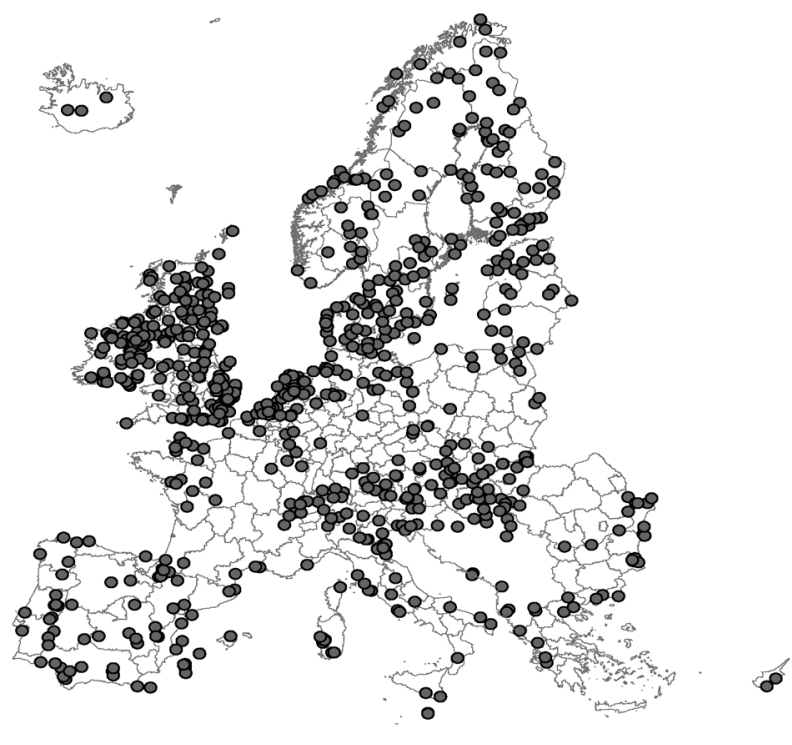

Designated areas according Ramsar convention

Figure 1: Ramsar sites in the European region. Source: Ramsar Convention Centre. 
Share of agricultural land (\%)

in EU at NUTS 2 level in 2003
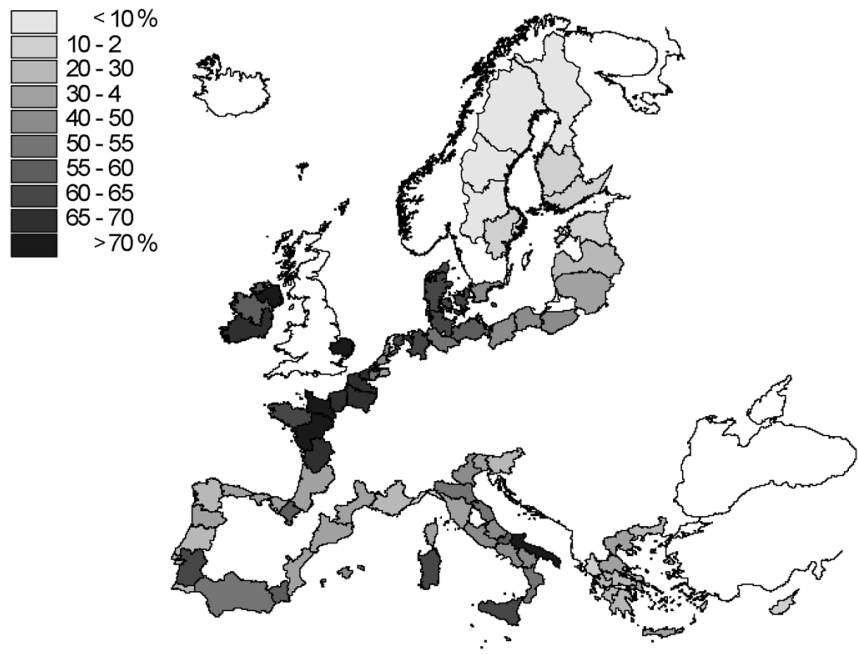

Figure 2: The proportion of agricultural land in the European coastal region. Source: EUROSTAT.
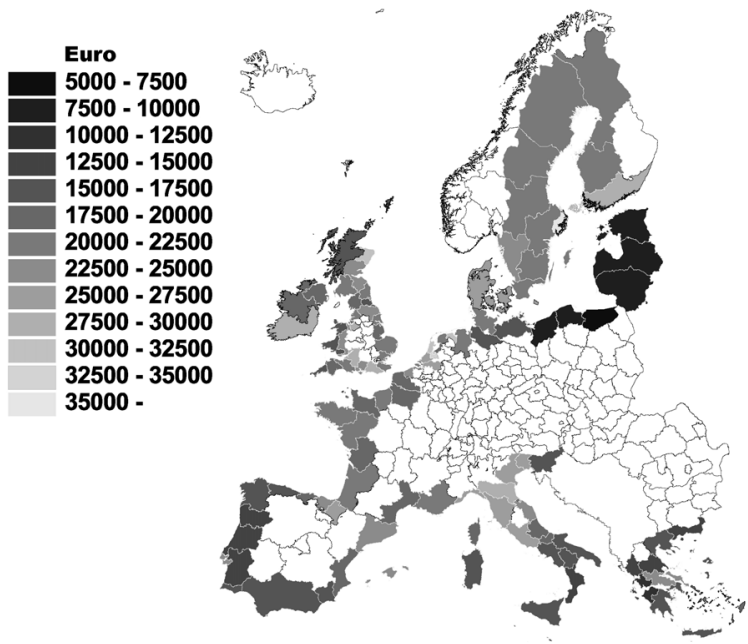

Figure 3: GDP per capita in 2002 (in Euros) by purchasing power standard. Source: EUROSTAT. 


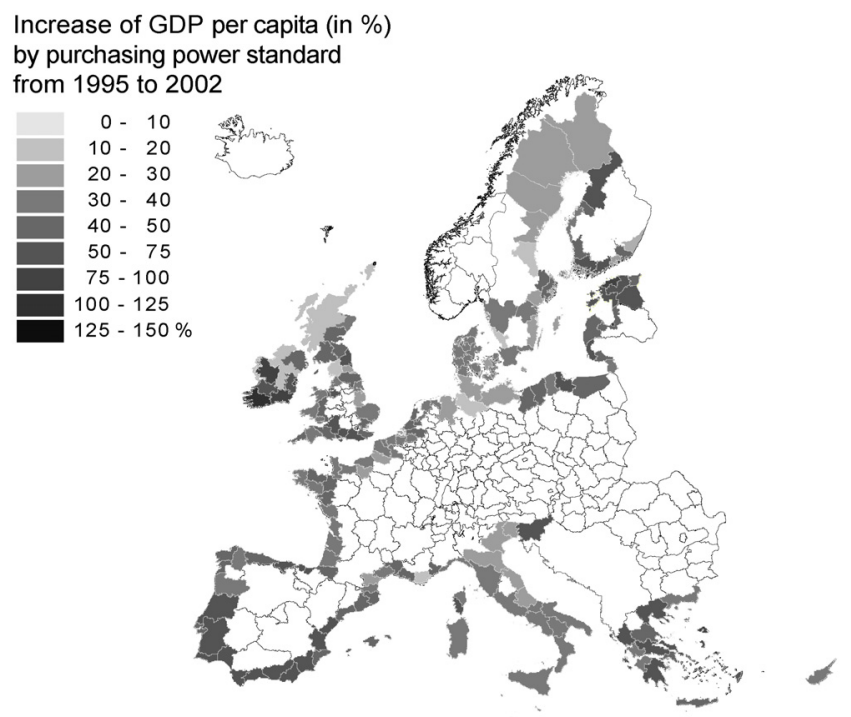

Figure 4: Increase in GDP per capita. Source: EUROSTAT.

The clusters are characterised by the following parameters.

Cluster 1. Economically and socially strong, the rate of development is moderate, but GDP is above the EU25 average. A high proportion of urban population combined with low unemployment, and environmental awareness is high.

Cluster 2. An economy that is stable and developing relatively slowly, with a high share of agricultural activities, a high share of rural population and relatively low GDP. This also causes a high rate of unemployment. Environmental awareness is marginal.

Cluster 3. A moderately developing economy which is slightly influenced by a high unemployment rate, partly caused by the high proportion of urban population. GDP is slightly below the EU25 average.

Cluster 4. Economically and socially very strong, a high proportion of urban population combined with high population density, low unemployment, a long coastline and well-developed environmental awareness.

Cluster 5 (Sensitive, Table 3). Rapidly growing economy combined with relatively high but decreasing unemployment, low but increasing income, and a low rate of R\&D investment. A low share of arable land but a high rural population. Despite the moderate length of the coast line, the highest proportion of coastline exposed to coastal erosion. Environmental protection has a high variability within the cluster (from $14 \%$ to $2 \%$ of area for designated areas). However, in the Baltic Sea coastal zone of this cluster, environmental and nature protection issues are of high importance. Therefore the conflicts between development and nature conservation issues are extremely relevant. 
Table 2: Clustering at NUTS 2 level. Parameters used for clustering. POP_DENSIT - Population density; UNEMP_2004 unemployment rate, \%_MEUR - change in GDP between 1995 and 2002 in millions of EUR; 2002 EU25_\% - relative GDP compared to EU 25 average; 02_95_ $\overline{\mathrm{CH}} \%$ - change (\%) in GDP per inhabitant by Purchase Power Standard compared to the EU25 average in \% from 1995 to 2002; 2002HABEUR - GDP (in EUR) per inhabitant by Purchase Power Standard compared to the EU25 average in \%; Agri\%_2003 - the percentage of agricultural land; Forest $\%$ 2003 - the percentage of forest land in the cell; RAMSAR - the number of Ramsar sites in the cell; R 1000SQKM - the number of Ramsar sites per $1000 \mathrm{sq} \mathrm{km}$; UrbanPop\% - the percentage of urban population in the area; Designated $\%$ - the share of nationally designated ecologically valuable areas in the cell; R\&D2004mEUR - spending on research and development in 2004; CLENGTH_KM - the length of coastline in the cell; COAST_EROD - the percentage of coastline exposed to erosion.

\begin{tabular}{lcccccc}
\hline Indicator & Cluster 1 & Cluster 2 & Cluster 3 & Cluster 4 & Cluster 5 & Cluster 6 \\
\hline POP_DENSIT & 182.6 & 161.3 & 127.5 & 279.8 & 183.3 & 207.1 \\
UNEMP_2004 & 6.3 & 13.6 & 12.1 & 5.3 & 10.1 & 9.5 \\
\%_MEUR & 43.9 & 52.1 & 58.6 & 55.8 & 76.5 & 30.7 \\
2002_EU25_\% & 109.6 & 77.3 & 82.9 & 142.3 & 68.8 & 97.3 \\
02_95_CH\% & -2.4 & -2.5 & 6.9 & 9.1 & 6.1 & -3.7 \\
2002HABEUR & $24,014.8$ & $15,635.4$ & $15,072.3$ & $34,006.9$ & $10,834.0$ & $22,009.1$ \\
Agri\%_2003 & 36.2 & 56.6 & 37.0 & 40.1 & 31.8 & 57.5 \\
Forest\%_2003 & 31.9 & 18.3 & 39.6 & 24.8 & 26.0 & 18.2 \\
RAMSAR & 5.6 & 1.9 & 2.7 & 8.4 & 2.0 & 3.2 \\
R_1000SQKM & 0.5 & 0.09 & 0.1 & 0.7 & 0.1 & 0.2 \\
UrbanPop\% & 77.2 & 67.0 & 76.0 & 78.0 & 57.9 & 78.4 \\
Designated\% & 7.1 & 8.0 & 8.0 & 9.4 & 4.7 & 15.1 \\
R\&D2004mEUR & 9999.8 & 6319.8 & 8946.0 & $14,769.0$ & 817.7 & $20,495.4$ \\
CLENGTH_KM & 967.5 & 688.3 & 679.3 & 1882.0 & 723.4 & 640.2 \\
COAST_EROD & 50.6 & 167.3 & 80.0 & 153.1 & 173.7 & 151.2 \\
\hline
\end{tabular}

Cluster 6. A traditionally strong and stable economy with a high proportion of agricultural activities. Population density is high and most of the population lives in urban areas. Despite the high living standard, a high level of R\&D expenditure is needed to avoid economic stagnation.

For our further activities we can consider Cluster 5 to be the most sensitive, one because of the highest degree of potential conflicts between development and environmental and social factors. Therefore the number of sensitive NUTS2 cells for further SENSOR project activities in coastal areas will be 23 (Table 3). 


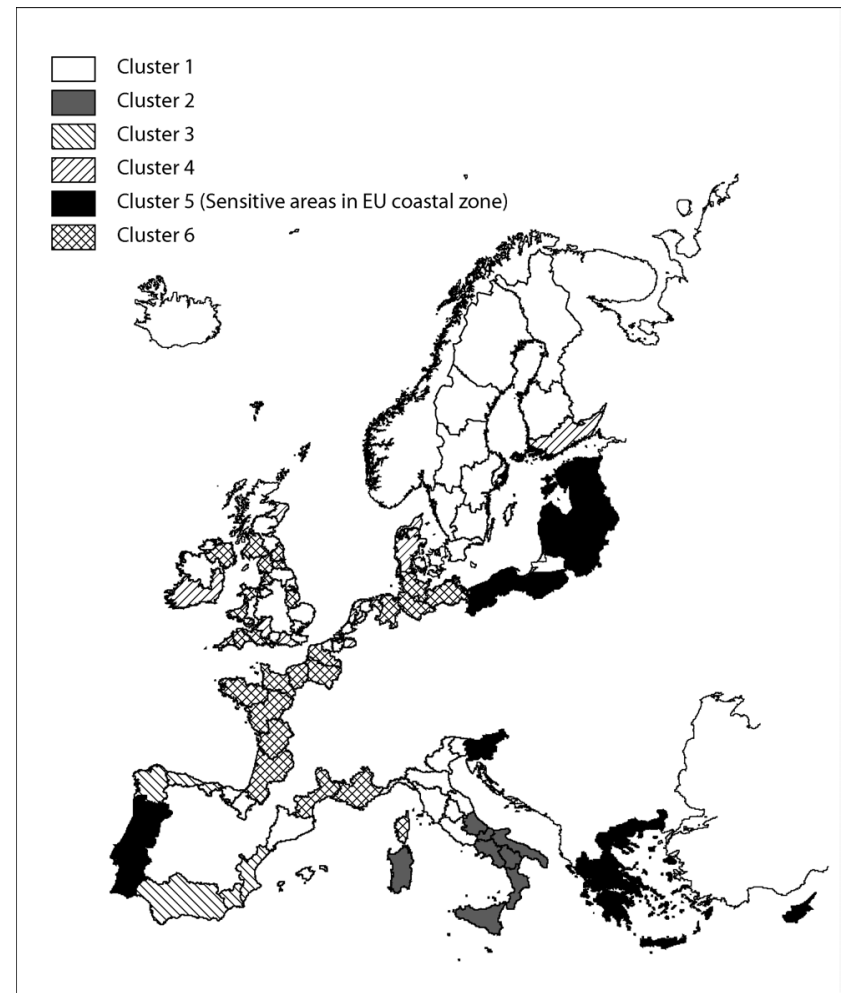

Figure 5: Regional clusters of European coastal zone based on economic, social and environmental indicators.

Table 3: $\quad$ Sensitive coastal NUTS2 cells.

\begin{tabular}{|c|c|c|c|}
\hline Code & NUTS2 region & Code & NUTS2 region \\
\hline EE00 & Eesti & LT00 & Lietuva \\
\hline GR11 & $\begin{array}{l}\text { Anatoliki } \\
\text { Makedonia, } \\
\text { Thraki }\end{array}$ & LV00 & Latvija \\
\hline GR12 & $\begin{array}{l}\text { Kentriki } \\
\text { Makedonia }\end{array}$ & PL42 & Zachodniopomorskie \\
\hline GR14 & Thessalia & PL62 & $\begin{array}{l}\text { Warminsko- } \\
\text { Mazurskie }\end{array}$ \\
\hline GR21 & Ipeiros & PL63 & Pomorskie \\
\hline GR22 & Ionia Nisia & PT11 & Norte \\
\hline GR23 & Dytiki Ellada & PT15 & Algarve \\
\hline GR24 & Sterea Ellada & PT16 & Centro (P) \\
\hline GR25 & Peloponnisos & PT17 & Lisboa \\
\hline GR30 & Attiki & PT18 & Alentejo \\
\hline GR41 & Voreio Aigaio & SI00 & Slovenija \\
\hline GR42 & Notio Aigaio & & \\
\hline
\end{tabular}


The other 5 NUTS2 areas also belonging to the sensitive cluster 5 are islands and should be handled considering specific island issues. These are CY00 Kypros / Kibris; GR43 - Kriti; MT00 - Malta; PT20 - Regićo Autonoma dos Açores; PT30 - Regićo Autonoma da Madeira.

\section{Conclusions}

The NUTSx level clustering resulted in 7 clusters which were not, however, well distinguished in terms of the SENSOR sensitivity areas concept. Therefore we provided the NUTS2 level clustering using the following indicators: population density, unemployment rate, change in GDP between 1995 and 2002 in millions of EUR, relative GDP compared to the EU 25 average, the change (\%) in GDP per inhabitant by the Purchase Power Standard compared to the EU25 average in \% from 1995 to 2002, GDP (in EUR) per inhabitant by Purchase Power Standard compared to the EU25 average in \%, the percentage of agricultural land; the percentage of forest land in the cell; the number of Ramsar sites in the cell, the number of Ramsar sites per $1000 \mathrm{sq} \mathrm{km}$, the percentage of urban population in the area; the share of nationally designated ecologically valuable areas in the cell, spending on research and development in 2004, the length of the coastline in the cell and the percentage of coastline exposed to erosion as parameters that gave six clusters that are logically distinguishable from each other. As a result, 6 clusters have been distinguished, among which Cluster 5 was found to be the sensitive one. The cluster consisting of the Baltic Sea coast of Estonia, Latvia, Lithuania and Poland, the Atlantic coast of Portugal, the Greek Mediterranean coast and the Slovenian coast is characterized by a rapidly growing economy combined with relatively high but decreasing unemployment, low but increasing income and a low rate of investment in R\&D. There is also a low proportion of arable land, but a high rural population. Despite the moderate length of the coastline, this cluster has the highest proportion of coastline exposed to coastal erosion. Environmental protection has a high variability within the cluster (from $14 \%$ to $2 \%$ of area for designated areas). In this area the potential risk of conflicts between development and conservation issues, which is the criterion for sensitivity, is highest. This region needs further attention from the European Commission.

\section{Acknowledgements}

This paper has been supported by the EU $6^{\text {th }}$ Framework Integrated Project "Sustainability Impact Assessment: Tools for Environmental, Social and Economic Effects of Multifunctional Land Use in European Regions" (SENSOR).

\section{References}

[1] Turner, R.K., Subak, S., Adger, W.N., Pressures, trends, and impacts in coastal zones: Interactions between socioeconomic and natural systems. Environ. Manage. 20(2), 159-173, 1996. 
[2] Vellinga, P., Klein, R.J.T., Climate change, sea level rise and integrated coastal zone management - an IPCC approach. Ocean Coast. Manage. 21(1-3), 245-268, 1993.

[3] Small, C., Nicholls, R.J., A global analysis of human settlement in coastal zones. J. Coast. Res. 19(3), 584-599, 2003.

[4] Loveland, T.R., Reed, B.C., Brown, J.F., Ohlen, D.O., Zhu, Z., Yang, L., Merchant, J., Development of a Global Land Cover Characteristics Database and IGBP DISCover from 1-km AVHRR Data. Int. J. Remote Sens. 21(6-7), 1303-1330, 1998.

[5] Shi, C., Singh, A., Status and interconnections of selected environmental issues in the global coastal zone. Ambio 32(29, 145-152, 2003.

[6] Fletcher, C.H., Sea-level trends and physical consequences - applications to the United States shore. Earth Science Reviews 32(2), 73-109, 1992.

[7] Michael, H.A., Mulligan, A.E., Harvey, C.F. 2005. Seasonal oscillations in water exchange between aquifers and the coastal ocean. Science 436(7054), 1145-1148.

[8] Fabbri, K.P., A methodology for supporting decision making in integrated coastal zone management. Ocean Coast. Manage. 39(1-2), 51-62, 1998.

[9] Pickaver, A.H., Gilbert, C., Breton, F., An indicator set to measure the progress in the implementation of integrated coastal zone management. Ocean Coast. Manage. 47(9-10), 449-462, 2004.

[10] European Commission. Demonstration programme on integrated management of coastal zones, 1996; document XI/102/96.

[11] Commission of the European Communities. Communication from the Commission to the Council and the European Parliament on integrated coastal zone management: a strategy for Europe, Brussels COM 547, final, 2000.

[12] Commission of the European Communities. Council Recommendation of the European Parliament and of the Council of 30 May, 2002 concerning the implementation of Integrated Coastal Zone Management in Europe, Brussels L 148/24, 2002.

[13] Helming, K., Kuhlman, T., Wascher, D.M., Sieber, S., Tabbush, P., Dilly, O., Firbank, L., Bach, H., Andersen, E., Tscherning, K., König, B., Müller, K., Wiggering, H. Sustainability Impact Assessment of multifunctional land use in the European policy context - the SENSOR project. In: Mander Ü., Helming. K., Wiggering, H. editors. Multifunctional Land Use: Meeting Future Demands for Landscape Goods and Services. Springer, Berlin, 200X Accepted.

[14] Davos, C.A., Sustaining co-operation for coastal sustainability. J. Environ. Manage. 52(4), 379-387, 1998.

[15] Söderqvist, T., Eggert, H., Olsson, B., Soutukorva, Å., Economic valuation for sustainable development in the Swedish coastal zone. Ambio 34(2), 169-175, 2005.

[16] Juhasz, F., An international comparison of sustainable coastal zone management policies. Mar. Pollut. Bull. 23, 595-602, 1991. 
[17] Shi, C., Hutchinson, S.M., Xu, S., Evaluation of coastal zone sustainability: an integrated approach applied in Shanghai Municipality and Chong Ming Island. J. Environ. Manage. 71(4), 335-344, 2004.

[18] Spangenberger, J.H., Environmental space and the prism of sustainability: Frameworks for indicators measuring sustainable development. Ecol. Indicators, 2(3), 295-309, 2002.

[19] Anker, H.T., Nellemann, V., Sverdrup-Jensen, S., Coastal zone management in Denmark: ways and means for further investigation, Ocean Coast. Manage. 47, 495-513, 2004.

[20] Irtem, E., Kabdasli, S., Azbar, N., Coastal zone problems and environmental strategies to be implemented at Edremit Bay, Turkey. Environ. Manage. 36(1), 37-47, 2005.

[21] Ehrlich, Ü., Oja, T., Planning of protection zones and management costs in protected coastal areas. In. Brebbia, C.A., Saval Perez, J.M., Garcia Andion, L., Villacampa, Y. editors. Coastal Environment V incorporating Oil Spill Studies. WIT Press, pp. 27-34, 2004.

[22] Dauvin, J.C., Lozachmeur, O., Capet, Y., Dubrulle, J.B., Ghezali, M., Mesnard, A.H., Legal tools for preserving France's natural zone management. Ocean Coast. Manage. 47(9-10), 463-477, 2004.

[23] Christie, P., Is integrated coastal management suitable? Ocean Coast. Manage. 48, 208-232, 2005.

[24] Laine, A., Kronholm, M., Bothnian Bay Life: towards Integrated Coastal Zone management. Env. Sci. Policy 8(3), 259-262, 2005.

[25] Stojanovic, T., Ballinger, R.C., Lalwani, C.S., Successful integrated coastal management: measuring it with research and contributing to wise practice. Ocean Coast. Manage. 47, 273-298, 2004.

[26] Davis, B., Regional planning in the US coastal zone: a comparative analysis of 15 special area plans. Ocean Coast. Manage. 47(1), 79-94, 2004.

[27] Morf, A. 2005. Public participation in municipal planning as a tool for coastal management: case studies from western Sweden. Ambio 34(2), 7483, 2005.

[28] Geskou, I., Developing the vision: Managing the coastal zone of Magnesia through information and consent. Coast. Manage. 31(2), 187-194, 2003.

[29] Barde, J., A metadata service for integrated management of knowledge related to coastal areas. Multimed. Tools Appl. 25(3), 419-429, 2005.

[30] Bruckmeier, K., Interdisciplinary conflict analysis and conflict mitigation in local resource management. Ambio 34(2), 65-73, 2005.

[31] Barker, A., Capacity building for sustainability: towards community development in coastal Scotland. J. Coastal Res. 75(1), 11-19, 2005.

[32] Buanes, A., Jentoft, S., Karlsen, G.R., Maurstad, A., Søreng, S., In whose interest? An exploratory analysis of stakeholders in Norwegian coastal zone planning. Ocean Coast. Manage. 47(3), 207-223, 2004.

[33] Sarda, R., Avila, C., Mora, J., A methodological approach to be used in integrated coastal zone management processes: the case of the Catalan coast (Catalonia, Spain). Estuar. Coast. Shelf Sci. 62(3), 427-439, 2005. 
[34] Matishov, G.G., Denisov, V.V., Kirillova, E.E., Role of a procedure of environment impact assessment (EIA) in elaborating the integrated project of managing the Barents Sea coastal zones. Ocean Coast. Manage. 41, 221-236, 1998.

[35] Chen, X.W., Using remote sensing and GIS to analyse land cover change and its impacts on regional sustainable development. Int. J. Remote Sens. 23(1), 107-124. 2002.

[36] Cave, R.R., Ledoux, L., Turner, K., Jickells, T., Andrews, J.E., Davies, H., The Humber catchment and its coastal area: from UK to European perspectives. Sci. Total Environ. 314-316, 31-52, 2003.

[37] Burak, S., Dogan, E., Gazioglu, C., Impact of urbanization and tourism on coastal environment. Ocean Coast. Manage. 47, 515-527, 2004.

[38] Bogdanowicz, R., Drwal, J., Maksymiuk, Z., Osinski, A., Water quality management in the period of considerable water consumption decrease. Water Sci. Technol. 44(2-3), 337-342, 2001.

[39] Buck, B.H., Krause, G., Rosenthal, H., Extensive open ocean aquaculture development within wind farms in Germany: the prospect of offshore comanagement and legal constraints. Ocean Coast. Manage. 47, 95-122, 2004.

[40] Krause, G., Glaser, M., Co-evolving geomorphological and socioeconomic dynamics in a coastal fishing village of the Bragança region (Pará, North Brazil). Ocean Coast. Manage. 46(9-10), 859-874, 2003.

[41] Laane, R.W.P.M., Brockmann, U., van Liere, L., Bovelander, R., Immission targets for nutrients $(\mathrm{N}$ and $\mathrm{P})$ in catchments and coastal zones: a North Sea assessment. Estuar. Coast. Shelf Sci. 62(3), 495-505, 2005.

[42] Valiela, I., Tomasky, G., Hauxwell, J., Cole, M.L., Cebrian, J., Kroeger, K.D., Operationalizing sustainability: Management and risk assessment of land-derived nitrogen loads to estuaries. Ecol. Appl. 10(4), 1006-1023, 2000.

[43] Carlberg, A., The SUCOZOMA program: results and challenges. Ambio 34(2), 62-64, 2005.

[44] Pacyna, J.M., Barrett, K., Namiesnik, J., The RU contribution to global coastal zone research: an ELOISE (European Land-Ocean Interaction Studies) project. Estuar. Coast. Shelf Sci. 62(3), 387-389, 2005.

[45] Brody, S.D., Highfield, W., Arlikatti, S., Bierling, D.H., Ismailova, R.M., Conflict on the coast: Using geographic information system to map potential environmental disputes in Matagorda Bay, Texas. Environ, Manage, 34(1), 11-25, 2004.

[46] Impact Assessment Guideline (2005). http://ec.europa.eu/governance/ impact/docs/SEC2005_791_IA\%20guidelines_annexes.pdf

[47] Arhonditsis, G., Karydis, M., Tsirtsis, G., Integration of mathematical modeling and multicriteria methods in assessing environmental change in developing areas: A case study of a coastal system. J. Coastal Res. 18(4), 698-711, 2002. 